\title{
Urbanization: A Catalyst for the Emergence of Squatter Settlements and Squalor in the Vicinities of the Federal Capital City of Nigeria
}

\author{
Opeyemi A. Zubair ${ }^{1}$, Lazarus M. Ojigi ${ }^{2}$, \& Richard A. Mbih ${ }^{1}$ \\ ${ }^{1}$ College of Arts \& Sciences, Department of Geosciences, University of Missouri-Kansas City, Kansas City, \\ United States \\ ${ }^{2}$ National Space Research and Development Agency (NASRDA), Pyakasa Junction, Umaru Musa Yar'Adua Way, \\ Abuja, Nigeria \\ Correspondence: Opeyemi A. Zubair, College of Arts \& Sciences, Department of Geosciences, University of \\ Missouri-Kansas City 5100 Rockhill Road, Kansas City, Missouri, 64110, United States. Tel: 1-81-6235-6006. \\ E-mail:oaz7x9@mail.umkc.edu
}

Received: January 20, 2015 Accepted: February 4, 2015 Online Published: March 30, 2015

doi:10.5539/jsd.v8n2p134 URL: http://dx.doi.org/10.5539/jsd.v8n2p134

\begin{abstract}
From the 1990s to date, growing deterioration of urban environmental quality, and the developments of squatter settlements and squalors have gradually become the attributes of the development patterns in the Federal Capital City (FCC), Abuja and environs in Nigeria. The FCC, Abuja and the surrounding towns and settlements popularly referred to as 'satellite towns' in Nigeria, are characterized by inadequate urban infrastructure, high rural-urban migration, population pressure, high cost of living, poor economic lifestyle, informal settlements and failing infrastructure. In view of these urban development dynamics and the prevailing economic situations in Nigeria, many citizens have resorted to building and settling in unapproved lands within and around the city. In attempts to maintain the designed land use and master plan of the city and to control the quality of infrastructural developments in the area, the relevant government authorities often employ the use of mass demolition of illegal constructions, and informal settlements; resulting in displacement of many inhabitants. A further repercussion of this process is the emergence of several unplanned settlements dotting the surroundings of the city area assumed to be outside the immediate development interest of the FCC authorities. This paper is therefore aimed at assessing the urbanization of the FCC, Abuja as a catalyst for the emergence of squatter settlements and squalors in and around the city. To achieve this, Landsat satellite images of Abuja in 1987, 2001 and 2006 were used in mapping and analyzing the spatial growth of the city. The results of the study showed that squatter settlements and squalors have sprang up in and around the study area due to poor housing scheme, which made proper accommodation within the city unaffordable for low income residents of the city who were mostly civil servants. It was argued in the paper that, though demolition exercise may be agreed by the Abuja City Administration as a necessity, this could be largely avoided if proper housing infrastructure is included in the planning process.
\end{abstract}

Keywords: Abuja, built-up, federal capital city, land cover, squatter settlements, squalor, satellite remote sensing, urbanization, Nigeria

\section{Background}

Settlements are products of human activities. They are dynamic and constantly changing with man's changing social and economic needs. Settlements have held a dominant place in early works (Brunhes, 1925) and in recent studies (Mesev, 2003). Forming a distinctive pattern on the landscape, settlements have been viewed as an expression of 'man-land' relationship. This relationship is manifested in the pressure that is exerted on land by population increase which often time, is responsible for the dynamics of settlement pattern. Notably, complex patterns can be observed in urban centers than is seen in rural areas due to population influx in urban centers.

Places designated as urban centers usually attract people; hence the high population normally associated with such places. There are many pull-factors that attract people to places designated as urban center. Abuja being the Federal Capital City of Nigeria has witnessed remarkable spatial and population growths due to such attractive factors normally associated with settlements designated as capital cities. In the 2006 population census of Nigeria, the population of Abuja was estimated at about 1.4 million people as against that of 1991 figures of 371,674 (National Population Commission, 2006). From a sparsely populated area, Abuja has within the last few 
decades become a center of population attraction. Of these population are the urban poor, urban rich and the middle class. This inequality in wealth distribution has resulted in inequality to land accessibility, which has encouraged the development of informal settlements or squatter settlements within and around the city. Unfortunately, limited resources by the concerned authorities, serves as a disadvantage to the urban poor. In the quest to seek for an abode, many of these low income residents often create squatter or informal settlements which are unplanned and indecent for living. From 1990 to date, growing deterioration of urban environmental quality, and the developments of squatter settlements and squalors have gradually become the attributes of the development patterns in the Federal Capital City (FCC), Abuja and its environs. The FCC, Abuja and the surrounding towns and settlements popularly referred to as 'satellite towns' are characterized by inadequate urban infrastructure, high rural-urban migration and population pressure, high cost of living and poor economic lifestyle, informal settlements and failing infrastructure. In view of these urban development dynamics and the prevailing economic situations in Nigeria, many citizens have resorted to building and settling in unapproved lands within and around the city.

This informal settlements need monitoring to assist development planners in stemming their development, and so that proper housing arrangements can be made without necessarily reflecting the inequalities that exist in wealth distribution. Squatter settlements usually have the highest concentration of poor people who tend to over stretch available facilities. While such places termed as squatter settlements serves as homes to many, oftentimes, such squatter settlements also serves as hideouts for hoodlums and are usually hubs of urban crimes. In some cases, such place are called urban slums.

However, Turner in Okoro (2014), argued that there is no city in the world without a slum. He clarifies the notion between slum and squatter settlements. According to him; all squatter settlements are slums while some slums are not squatter settlements because dwellers of such slum have a title deed of those lands they develop upon. In Africa, the emergence of slums and informal settlements arises as a result of rapid population growth and rural-urban migration which places enormous pressure on the ability of African countries to facilitate access to housing and public services, as manifested by the high housing rents, overcrowding, and emergence of slums and informal settlements (Dumashie, 2006). Ojigi (2012), observed that informal settlements has serious aesthetic and functional effects on the landscape and sustainable development of a city. Often times, they also serve as the origin of disease outbreak. This is one of the main reasons while many of these informal settlements in Abuja have constantly been a target for demolition by the government of Nigeria.

Squatter settlements in Abuja exists because there is no inclusion of the urban poor in the city planning process. This is reflected in the unguarded utterances of a former minister of the Federal Capital Territory (FCT) Naisr EL Rufai that: "Abuja is not for the poor" (Okoro, 2014). The poor and non-privileged are continuously been pushed away from the city to give room for the relatively few rich, powerful and influential, forcing the poor to resort to ordinarily uninhabitable slums, that are also at the risk of being removed in the future (Okoro, 2014).

Bello (2009), categorized squatter settlements in Nigeria into two namely; the illegally occupied settlements and the illegally developed settlements both of which can develop as a commercial or residential enclave at first, and then evolve into settlements of mixed activities at the later stage. According to Bello (2009), abandoned government acquired lands for reasons such as non-payment of compensation, project abandonments and change in government and government personnel is the major culprit for the development of illegally occupied settlements. On the other hand, illegally developed squatter settlements usually develop at rural urban fringes as a result of land speculators buying agricultural lands, and laying it out without provision for adequate roads, and other basic infrastructures with the expectations that government would in the future provide these basic infrastructures (Bello, 2009). Unfortunately, the limited resources of the government, and the low development priority of these places has in many cases proven these speculators wrong. Often times, priorities are given to the wealthy and the powerful politicians, who have the power and resources to influence infrastructural development to their areas of interest. This situation therefore leads to the development of squatter settlements where necessary approval from Town Planning Authorities is lacking (Olaranwaju, 2001). The lack of adequate infrastructures in these areas often result into improper disposal of wastes, lack of good water supply and insecurity, among others. While there is no adequate statistic accounting for the total population of people within the Abuja squatter settlements, a stage one report of Abuja Geographic Information Systems in 2004 states a total of twenty eight squatter settlements exists within the FCT. Of these twenty eight, only two fell outside of the Federal Capital City (Abuja). According to this report, these settlements occupied a total of 2, 412 ha. This is by all means very high. These report did not account for the squatter settlements located in the neighboring States where the Abuja City administrators have no jurisdiction. Many times, the State government of these 
place have no drive to enforce plan for development. Such places include Mararaba and Karu in Nassarawa State among others.

Settlements whether informal or formal, requires constant monitoring. This is especially true in most developing countries including Nigeria. Where proper and periodic monitoring of formal settlements is not carried out, there is a very high tendency for informal settlements to develop. The reason is that, a substantial part of the population in many developing countries are still poor. These poor population are highly unstable as they move easily in search of a better living. The urban centers are usually an attracting place for these population group. Unfortunately the lack of proper planning for these population group encourages the development of squatter or informal settlements in many developing countries' urban centers.

Although different definitions of informal settlement do exist, slum, favella, squatter settlement or shanty town are commonly used synonyms for this special type of settlement (Hofmann, 2008). They have been defined as areas where groups of housing units have been constructed on land that the occupants have no legal claim to, or occupy illegally; or unplanned settlements and areas where housing is not in compliance with current planning and building regulations (UNSTAT, 2005). An estimated 1.5 billion people will live slums, favelas or shanty towns' world wide by 2020 (UN-HABITAT, 2006a). As a result, there is the need to have a means of monitoring these problem in a timely and cost effective way.

Efforts in monitoring the dynamics of settlement growth using remote sensing and GIS have been demonstrated by many researchers (Olorunfemi, 1983, Herold, et al., 2003, Moeller, 2005, Zubair, 2008, Hofmann, 2008). Others have in recent times, directed efforts towards settlement growth in the area of sprawl (Duncan et al., 1989, Frank, 1989, Kunstler, 1993, Burchell et al., 1998, Kahn, 2000, Freeman, 2001, Ji, 2008 and Ade and Afolabi, 2013). These studies are becoming very important because of the impact of settlement growth on important land resources. While adequate methods have been developed in mapping and monitoring formal settlements, the challenge lies in having appropriate methods to detect and monitor the spatial behavior of informal settlements reliably (Hofmann, 2008). Although remotely sensed data provides the needed data source, the methods of feature extraction and the satellite image resolution to be adopt is an important factor that should be considered. Where cost is an issue, a compromise for lower resolution with adequate field verification is an alternative. Although detecting squatter settlements from lower resolution images is difficult, however, it requires less sophisticated techniques and the images are usually free. This can ensure that consistent monitoring of squatter settlement prone areas are regular and timely. To effectively monitor informal settlement growth, it is necessary to have information on existing land use land cover, and have the capability to monitor the dynamics of land use resulting out of both changing demands of increasing population, and forces of nature acting to shape the landscape.

The basis of using remote sensing data for monitoring settlement and land use dynamics is that changes in land use result in changes in radiance values which can be remotely sensed. According to Ojigi (2006), land use and land cover recognition and supervised classification of an urban environment or landscape depends largely on three major factors, namely; good knowledge of the area of study through thorough fieldwork and ground truthing exercises, good training sites and the spectral signatures or image characteristics of the image data to be used. Remote sensing provides the most synoptic and easy access to temporal mapping of urban growth and analysis.

\subsection{Federal Capital Territory Resettlement Policy}

The first policy statement to relocate the former capital of Nigeria from Lagos State to the current location (Figure 4) was given in 1976 by the then Military Head of State; General Murtala Mohammed. Subsequently, the FCT Act which vests the entire 8,000 square kilometers of the FCT land area in the Federal Government of Nigeria was enacted in 1976 (Jibril, 2006). This Act states that “...the ownership of the lands comprised in the Federal Capital Territory shall likewise be vested absolutely in the Government of the Federation" (FCT Act, 1976). The essence of this policy was to ensure an "equal citizenship" within the FCT where no one can "claim any special privilege of "indigeneity" as was the case with the former capital (Jibril, 2006). This brought about the need to resettle the original settlers of the FCT area into new locations. To achieve this, an economic census of assets of all the original settlers of the territory was carried out with a commitment to pay compensation for all their owners outside of the territory (Mabogunje in Ayileka et al, 2001). However, the extremely high cost of doing this led to a change of this policy (Jibril, 2006). The first policy change occurred in 1978 when it became clear that resettling the original inhabitants of the area would encourage the growth of tse tse fly, which earlier ecological survey of the area in 1977 had revealed still exist in a large part of the territory (Jibril, 2006). A total resettlement without immediate development of the area would encourage the multiplication of these flies. This would have compromised the health of the future inhabitants if the original plan had been carried out. The 
decision to evacuate all the inhabitants had to be revised, and compensation and resettlement undertaken only in respect of those occupying the sites chosen for building the city (Mobagunje, 1977). Further, "a detailed study of the area in question, had made it clear that the local inhabitants within the Territory were far from being 'few' in fact well over 316,000 people were enumerated and not the 25,000 - 50,000 earlier thought. It was then decided that the funds required for their compensation was much higher than had earlier thought. In these circumstances, resettlement costs would have been astronomical, and would have delayed the development of the new capital. (Mobagunje, 1977).

By the December of 1992, a shift in policy from resettlement to integration was adopted. By this, only people that will be affected by construction of access roads and other infrastructures were to be resettled (Jibril, 2006). This is in the attempt to reduce cost. However, in 1999, the "Integration Policy" was reversed for that of complete resettlement again and a new resettlement town was embarked on and completed in 2002 (Jibril, 2006).

However, as Jibril, (2006) stated it, "while the people affected were fully prepared for movement to the new location, another policy change happen. In preparation for the 2003 general election the additional security personnel brought into the Federal Capital Territory occupied the buildings under the resettlement scheme. The Government looked the other way - perhaps out of political expediency" and the resettlement never occurred. Yet, because the government realized that the original master plan could not be implemented without resettling the people, a well-articulated resettlement policy was developed. This is the fourth policy which in actual sense, is a revisit of the old resettlement policy. However, in the desperation to enforce the original master plan, by 2006, demolition exercises began even before the resettlements were carried out and many of the squatter settlements (Figure 1) within Abuja were affected (Figures 2 and 3).

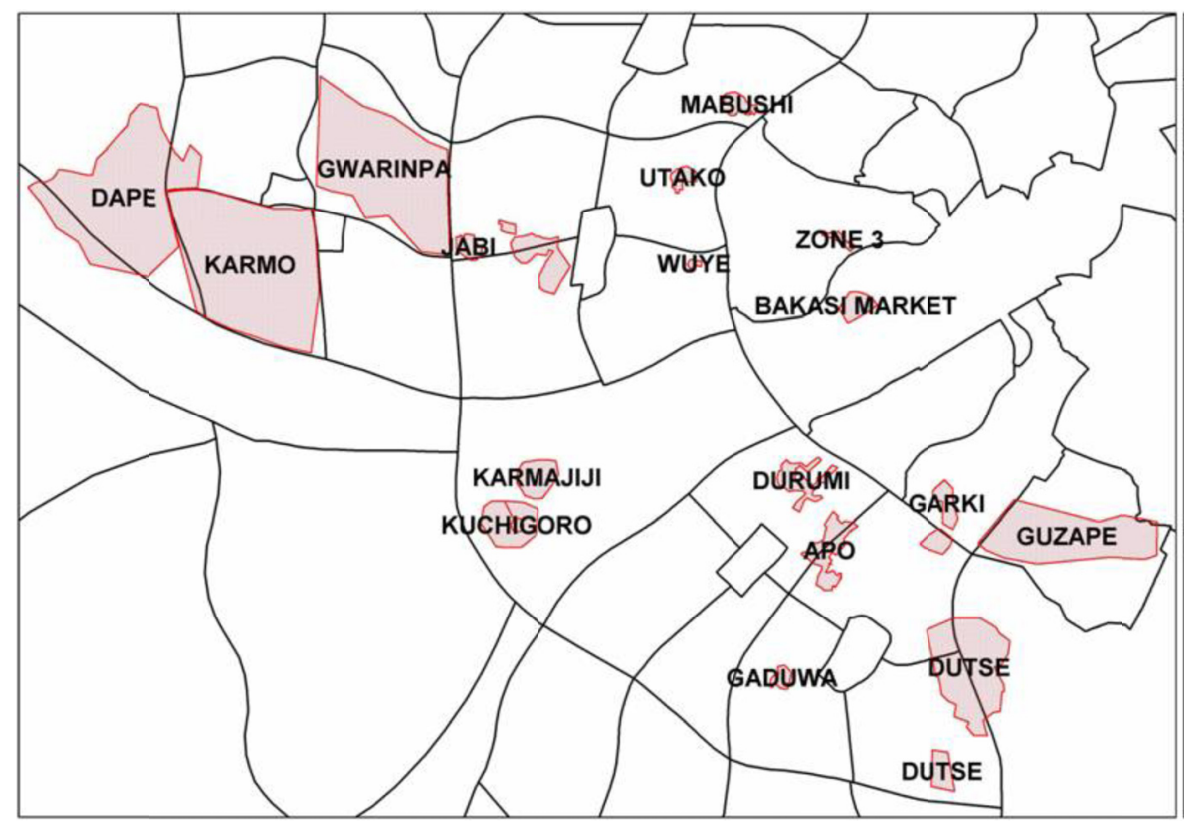

Figure 1. Federal capital city squatter settlements (AGIS, 2006 in Jubril, 2006)

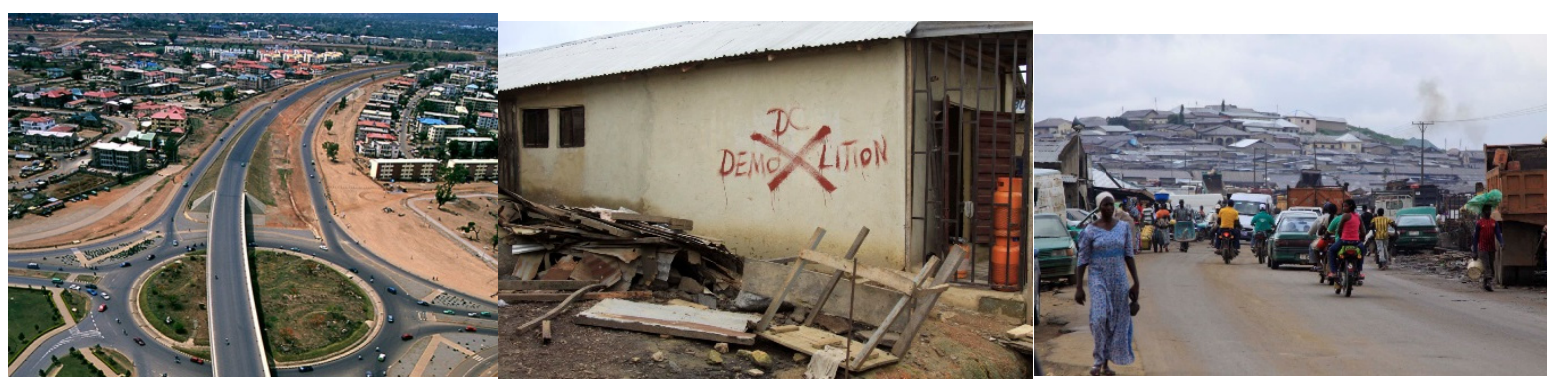

Figure 2. (a) A view of Parts of FCC, Abuja, Nigeria (left); (b and c) squatter settlements in Mpape Area of Abuja (middle and right) 


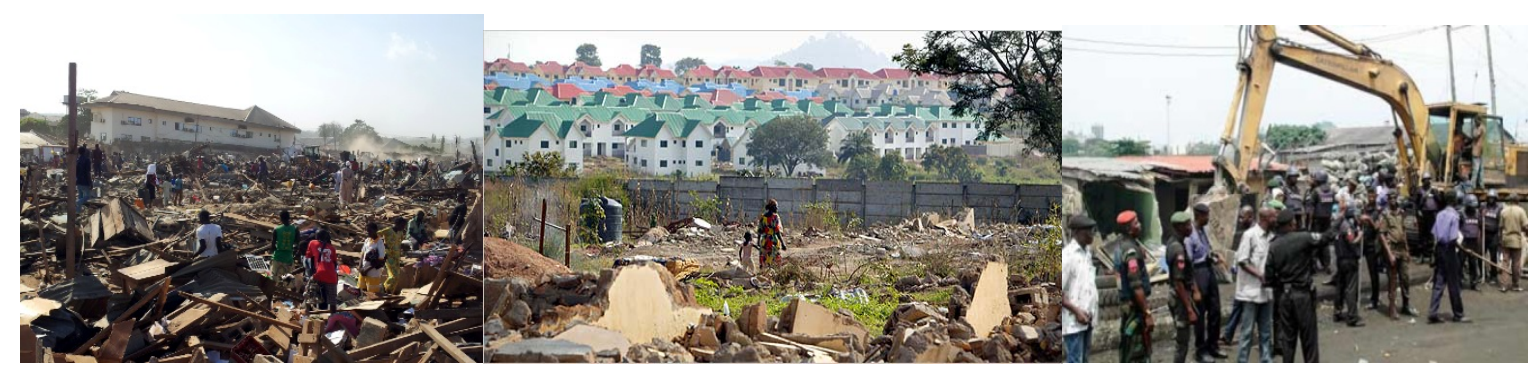

Figure 3. Sites of demolished illegal settlements in Apo Mechanic Village (left) and Mpape Satellite Town (middle and right), FCC, Abuja, Nigeria

In recent times, the Abuja Metropolitan Management Council had marked and demolished structures in Mpape near highbrow Maitama area, and other settlements such as Idu, Karmo, Dape, Tasha, Gwagwa, Saburi, Zauda, Jahi and Gishiri, Mabushi, Kuchigoro, Chika, Aleita, Piwoyi, Lugbe, Pyakassa, Tudun-Wada, Dei-Dei and Guzape Majority of the property owners in the emerging squatter settlements are left with no alternative than to look for alternative accommodation before the arrival of the demolition teams. However, a further repercussion of this process is the emergence of several unplanned settlements dotting the surroundings of the city area assumed to be outside the immediate development interest of the FCC authorities. Bearing the above in mind, this study seeks to map the settlement growth in Abuja area between 1987 and 2006 using medium resolution satellite data. The goal is to determine the socio-economic implication of the settlement growth between these periods as it relates to the development of squatter settlements and squalor within and in the surrounding areas of the city.

\subsection{Problem Statement}

Abuja is the Federal Capital City of Nigeria. The city has witnessed remarkable spatial and population growths due to pull-factors normally associated with settlements designated as capital cities. Notably, over the years, remarkable and observable patterns have developed both within and in the neighboring areas of the city. This has brought to view, the need to monitor and document these patterns so as to protect the original master plan of the city. The development of remote sensing (RS) and Geographic Information System (GIS) over the years has proven to be valuable tools in monitoring, and documenting growth and patterns in settlements. Particularly, high resolution satellite images have proven very useful in mapping settlement growth. However, the cost of acquiring high resolution images have made them inaccessible for such studies. In this regard, this paper seeks to explore the opportunities provided by free medium resolution Landsat satellite data to map the emerging settlement patterns in an around Abuja.

\subsection{Goal}

The goal of this study is to use medium resolution Landsat images to capture the emerging settlement patterns (particularly squatter settlements) due to population growth in Abuja and its environs.

\subsection{Objectives of the Study}

Therefore, the objectives of the study are to:

i. Develop the land use land cover maps of Abuja and its environs using multi-temporal Landsat satellite imageries of the study area

ii. Determine the magnitude of built-up areas resulting from the urbanization processes in relation to other land cover types in the study area using Remote Sensing and Geographic Information System (GIS) techniques;

iii. Compute the spatial extent and changes in the Land use and Land cover types in the FCC, Abuja for each year under study;

iv. Determine the annual rate of changes in the land use land cover and develop a predictive model for LULC change detection in FCC, Abuja and environs;

v. Evaluate the socio-economic implications of the emerging settlement patterns in the study area.

\subsection{Scope of the Study}

The focus of this paper is the mapping of built-up areas in and around the Federal Capital City (FCC) of Nigeria using medium resolution satellite imageries. The purpose of this is to evaluate the implications of this growth in 
the emergence of squatter settlements and squalor in the vicinities of the city. The datasets are mainly 1987, 2001 and 2006 Landsat imageries FCC, Abuja and environs. While land cover of the whole area was produced, the built-up which represents human settlement was extracted and used as a proxy for identifying squatter settlement.

\subsection{Study Area}

Abuja with a population of about 1.4 million (NPC, 2006) is the capital city of Nigeria and one of the 10 most populous cities in Nigeria. Abuja is strategically located in the center of Nigeria (Figure 4), and its main physical developments commenced in 1980. After about thirty-five years, it has grown into one of the fastest developing cities in Africa. The site was chosen for Nigeria's new capital because of its central location, easy accessibility, salubrious climate, low population density, and the availability of land for future expansion (Encyclopedia Britannica, 2014). It was the first planned city to be built in Nigeria.The FCT is bounded on the north by Kaduna State, on the west by Niger State, on the east and south-east by Plateau State, and on the south-west by Kogi State. It falls within latitude $7^{\circ} 25^{\prime} \mathrm{N}$ and $9^{\circ} 20^{\circ}$ North of the Equator and longitude $5^{\circ} 45^{\prime}$ and $7^{\circ} 39^{\prime}$ (Federal Capital Territory Administration, 2011).

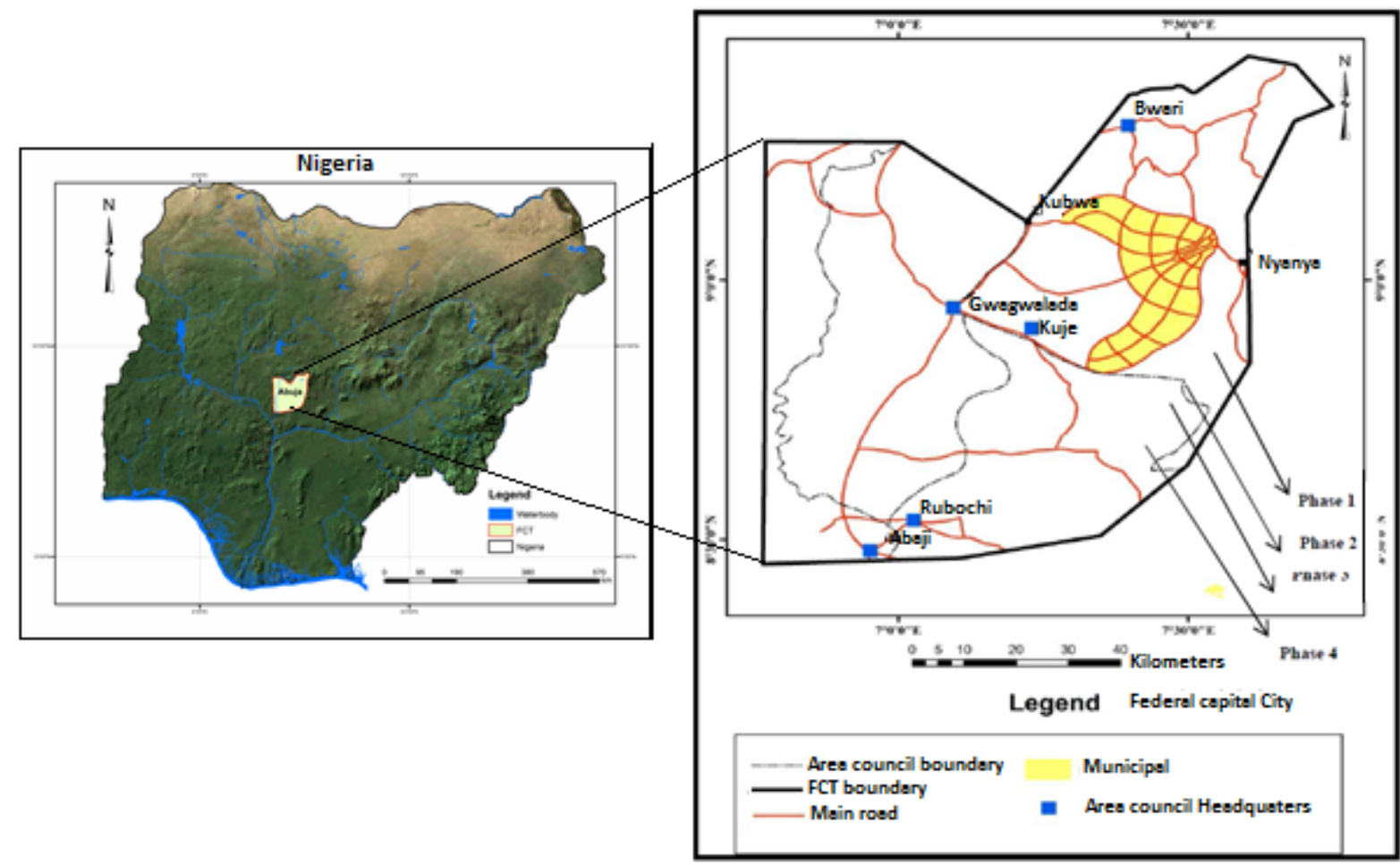

Figure 4. Map of Nigeria showing the location of FCT

Source: Modified from Ukoje and Kanu, 2014

\section{Research Materials and Methods}

\subsection{Datasets}

Table 1. Datasets used

\begin{tabular}{|c|c|c|c|c|c|}
\hline S/No & Name of Data & $\begin{array}{ll}\text { Spatial resolution } \\
\text { and scale }\end{array}$ & Date of Data & Data Type & Source(s) \\
\hline 1 & Landsat & $30 \mathrm{~m}$ & $1987,2001,2006$ & Satellite imagery & Global land Cover Facility \\
\hline 2 & Map of Abuja & & 2006 & Shapefile & Nigerian Space Agency \\
\hline 3 & SPOT 5 & $5 \mathrm{~m}$ & 2006 & Satellite imagery & Nigerian Space Agency \\
\hline
\end{tabular}

SPOT 5 of Abuja (used as a guide together with Google Earth imagery in training the data and crosschecking the random reference points used for accuracy assessment) 


\subsection{Development of Classification Scheme}

Based on a prior knowledge of the study area and the use of additional information from previous research in the study area (Ade and Afolabi, 2014), a classification scheme was developed for the study area which gives a rather broad classification where the land cover types were identified by single digits. Five land cover types which can be effectively distinguished on the medium resolution images were identified. Going beyond these five categories will likely increase errors in the image classification. Therefore, these five classes were chosen. Built-up depicts residential areas, shopping centers, industrial and commercial facilities, highways and major streets, and associated properties and parking lots. Thick vegetation covers areas of land with collection of trees. Sparse vegetation includes areas with grasses, brush, crops and in general, non-forest vegetation. Water body depicts open water bodies such as lakes, ponds, streams and rivers. Rocky/Bare Surfaces denotes lands without shrubs, sandy areas, rocky areas and other human induced barren lands.

Table 2. LULC classification scheme

\begin{tabular}{ll}
\hline Code & Land Cover Category \\
\hline $\mathbf{1}$ & Built-up Land \\
$\mathbf{2}$ & Rocky/Bare Surfaces \\
$\mathbf{3}$ & Thick vegetation \\
$\mathbf{4}$ & Sparse Vegetation \\
$\mathbf{5}$ & Water Body \\
\hline
\end{tabular}

\subsection{Methods of Data Analysis}

The following methods of data analysis were adopted for this study

(i) Supervised classification with Maximum Likelihood technique

(ii) Accuracy Assessment with 250 reference points

(iii) Calculation of the Area in hectares of the resulting land cover types for each study year and subsequently comparing the results

(iv) Annual Rate of Change - percentage change divided by 100, multiplied by the number of study years expressed as: \% Change/100* \# of Study years

(v) Recode - to extract built-up land out of the remaining classes since this is the focus of this paper

\subsubsection{Maximum Likelihood Classification}

The maximum likelihood procedure is a supervised statistical approach to pattern recognition and based on the assumption that, the frequency distribution of the class membership can be approximated by the multivariate normal probability distribution. Maximum likelihood classifier assumes that a pixel has a certain probability of belonging to a particular class, and that these probabilities are equal for all classes and the input data in each band follows the Gaussian (normal) distribution function (Lillesand et al., 2008). The probability of a pixel belonging to each of a predefined set of classes is calculated, and the pixel is then assigned to the class for which the probability is the highest. It involves the collection of sample pixels known as training sites, and the use of the sample pixels in classifying features on the satellite image. Maximum likelihood classifier is one of the most popular methods for thematic mapping with satellite multispectral imagery.

\subsubsection{Accuracy Assessment}

Accuracy Assessment which examines how closely the land cover maps generated matches other reference maps or high resolution image of the same area was carried out. In this case, google earth high resolution images and SPOT satellite data were used as the reference map. However, for this to occur, an appropriate technique must be employed. The error matrix approach well described by Jenson (2005) was employed. An error matrix is a means of reporting site-specific error (Campbell, 1987). The error matrix is derived from a comparison of reference map pixels to the classified map pixels and is organized as a two dimensional matrix. From the error matrix, several measures of classification accuracy can be calculated, including percentage of pixels correctly classified, errors of omission, and errors of commission (Senseman, 1995). In addition, statistical measures such as the Kappa Coefficient of Agreement, Kappa variance, and Kappa standard normal deviate can be calculated from the 
error matrix. Kappa is widely applied to evaluate the overall agreement of quantity and spatial location (Wang et al., 2013).

\section{Results and Discussion}

This paper made use of the objectives of this study as the basis of all the analysis carried out. The results are presented inform of maps and tables. They include the static and change in land cover of each class as derived from the Landsat satellite images used, with their accuracy assessments. The land cover distribution for each study year as derived from the land cover maps is shown in tables $3-8$ and figures 5 and 6 . Tables $3-5$ presents a summary of land cover distribution in the study area between 1987 and 2006.

Table 3 represents the static land cover category for the periods between 1987 and 2006. A total of 731.594 ha $(0.6 \%)$ of the area of interest were unclassified in 1987 . Thick vegetation and sparse vegetation had the highest percentage of $46.2 \%$ and $32.1 \%$ respectively while bare surfaces had just $15.9 \%$ and water, $0.7 \%$ of the total area of interest. Indeed, Built-up represents $4.5 \%$ of the total land area under classification. Though Abuja was created in 1976, it is not surprising that it accounted for a very low percentage in size as movement of people to Abuja from the then capital of Nigeria which was in Lagos had not taken place at this time. However, it should be noted that the movement process from Lagos to Abuja was designed to be in phases therefore, preparation towards the movement of people from Lagos was already in process with construction work going on. This accounted for the rather small size of built-up at this time.

Table 3. Land cover distribution $(1987,2001,2006)$

\begin{tabular}{lcccccc}
\hline \multirow{2}{*}{ Land Cover Categories } & \multicolumn{2}{c}{$\mathbf{1 9 8 7}$} & \multicolumn{2}{c}{$\mathbf{2 0 0 1}$} & \multicolumn{2}{c}{$\mathbf{2 0 0 6}$} \\
\cline { 2 - 7 } & Area (Ha.) & \% & Area (Ha.) & \% & Area (Ha.) & \% \\
\hline Built-up Land & 5994.97 & 4.5 & 9765.75 & 7.4 & 23599.3 & 17.8 \\
Rocky/Bare Surfaces & 21115.3 & 15.9 & 45365 & 34.2 & 18503.2 & 14.0 \\
Thick Vegetation & 61257 & 46.2 & 27050.3 & 20.4 & 22687.4 & 17.1 \\
Sparse Vegetation & 42535 & 32.1 & 48666.4 & 36.7 & 66221.5 & 50.0 \\
Water Body & 928.483 & 0.7 & 984.041 & 0.7 & 864 & 0.7 \\
Unclassified & 731.594 & 0.6 & 731.594 & 0.6 & 674.19 & 0.5 \\
Total & 132562.347 & $100 \%$ & 132563.085 & $100 \%$ & 132549.59 & $100 \%$ \\
\hline
\end{tabular}

Table 4. Summary accuracy assessment

\begin{tabular}{|c|c|c|c|c|c|c|}
\hline \multirow{2}{*}{ Land Cover Categories } & \multicolumn{2}{|c|}{1987} & \multicolumn{2}{|c|}{2001} & \multicolumn{2}{|c|}{2006} \\
\hline & P.A & U.A & P.A & U.A & P.A & U.A \\
\hline Built-up Land & $57.14 \%$ & $72.73 \%$ & $56.76 \%$ & $95.45 \%$ & $83.33 \%$ & $84.91 \%$ \\
\hline Rocky/Bare Surfaces & $60.00 \%$ & $33.33 \%$ & $83.33 \%$ & $28.41 \%$ & $37.50 \%$ & $37.50 \%$ \\
\hline Thick Vegetation & $96.88 \%$ & $50.82 \%$ & $64.41 \%$ & $88.37 \%$ & $56.14 \%$ & $80.00 \%$ \\
\hline Sparse Vegetation & $52.26 \%$ & $93.10 \%$ & $63.11 \%$ & $80.21 \%$ & $88.29 \%$ & $75.97 \%$ \\
\hline Water Body & $100.00 \%$ & $100.00 \%$ & $50.00 \%$ & $100.00 \%$ & $75.00 \%$ & $100.00 \%$ \\
\hline Overall Kappa & \multicolumn{2}{|c|}{$\mathbf{0 . 4 5 8 7}$} & \multicolumn{2}{|c|}{0.5089} & \multicolumn{2}{|c|}{0.6290} \\
\hline Overall Classification Accuracy & \multicolumn{2}{|c|}{$64.80 \%$} & \multicolumn{2}{|c|}{$64.80 \%$} & \multicolumn{2}{|c|}{$74.80 \%$} \\
\hline
\end{tabular}

P.A = Producer's Accuracy, U.A = User's Accuracy

Where producer's accuracy is the probability that a reference pixel will be correctly classified (omission error). The user's accuracy is the probability that a pixel classified on the image actually represent that category (class) on ground (commission error). 
Table 5. Land cover change of Abuja and its environs: 1987, 2001 and 2006

\begin{tabular}{lcccccc}
\hline \multirow{2}{*}{$\begin{array}{c}\text { Land Cover } \\
\text { Categories }\end{array}$} & \multicolumn{2}{c}{$\mathbf{1 9 8 7 - 2 0 0 1}$} & \multicolumn{2}{c}{$\mathbf{2 0 0 1 - 2 0 0 6}$} & \multicolumn{2}{c}{ Annual Rate of Change } \\
\cline { 2 - 7 } & $\begin{array}{c}\text { Change in } \\
\text { Hectares }\end{array}$ & \% Change & $\begin{array}{c}\text { Change in } \\
\text { Hectares }\end{array}$ & \% Change & $\mathbf{1 9 8 7 - 2 0 0 1}$ & $\mathbf{2 0 0 1 - 2 0 0 6}$ \\
\hline Built-up Land & 3770.78 & $2.9 \%$ & 13833.55 & $10.4 \%$ & 0.41 & 0.52 \\
Rocky/Bare Surfaces & 24249.7 & $18.3 \%$ & -26861.8 & $-20.2 \%$ & 2.6 & 1.01 \\
Thick Vegetation & -34206.7 & $-25.8 \%$ & -4362.9 & $-3.3 \%$ & 3.6 & 0.2 \\
Sparse Vegetation & 6131.4 & $4.6 \%$ & 17555.1 & $13.3 \%$ & 0.6 & 0.7 \\
Water Body & 0 & $0 \%$ & -57.404 & $-0.1 \%$ & 0 & 0.005 \\
\hline
\end{tabular}
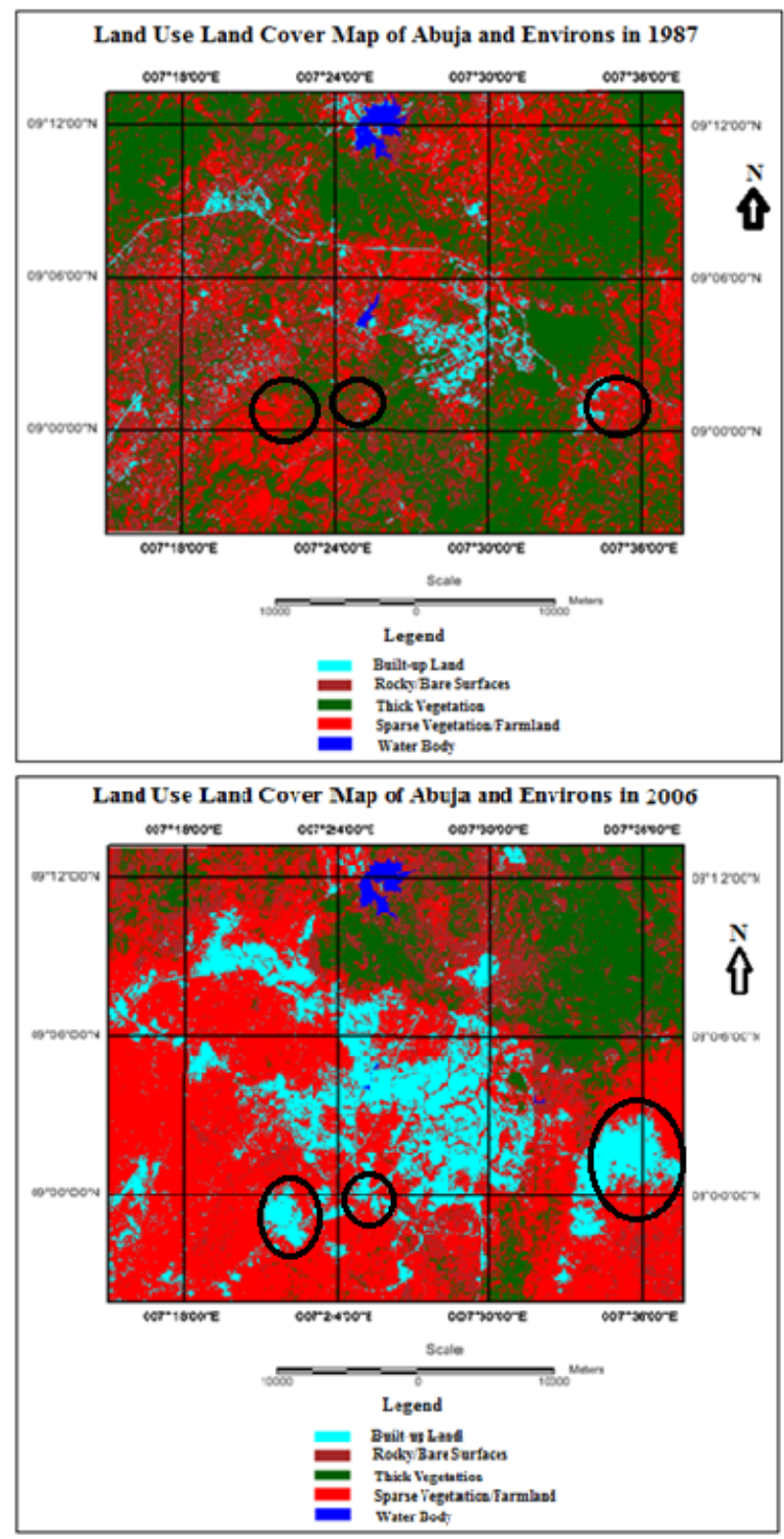

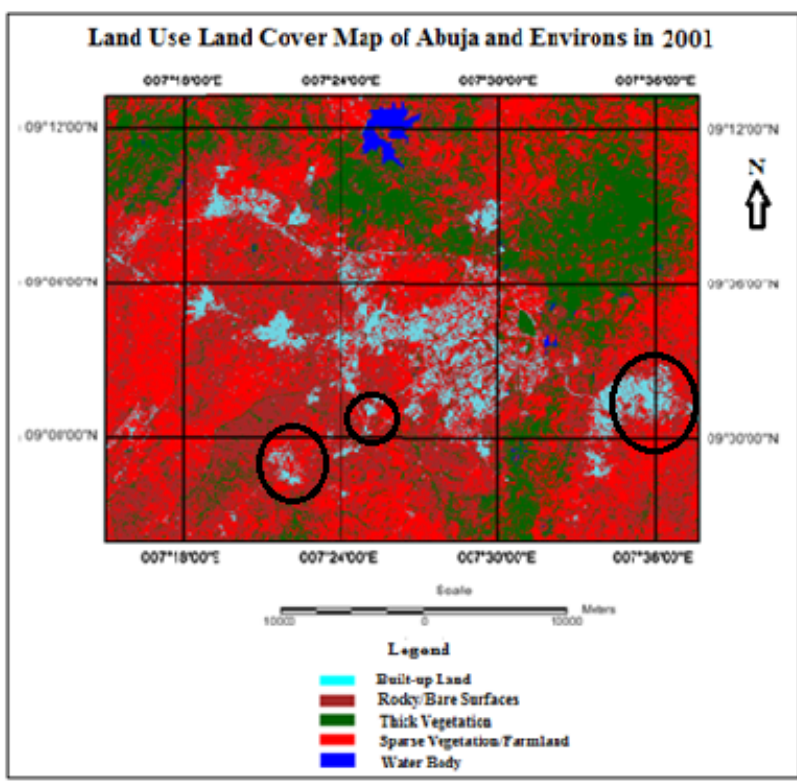

Large patches of squatter settlemnts exist in the areas that are circled on the maps. These areas include Karu, Lugbe and the Pyakassa areas of the City.

Figure 5. Land cover Map of Abuja-Nigeria in 1987, 2001 and 2006 as derived from Landsat satellite data of these years 
Figure 5 reflects the spatial expansion of the areas with large squatter settlements as the city itself develops. The city can be seen clearly surrounded by squatter settlements. In 1987, there were almost no developments in some of the areas where squatter settlements exist today. But as the city expands and adequate housing infrastructure is not provided for the urban poor, unplanned settlement patterns different from the patterns in the city began to emerge in the vicinities of the city (Figure 5). As can be seen, the density of squatter settlements was higher on the 2001 image compared to 1987 . Within the city itself, there are pockets of squatter settlements scattered across the city which the resolution of the image used could not reveal.

Table 6. Accuracy and Kappa Total for 1987

\begin{tabular}{lcccccc}
\hline Class Name & $\begin{array}{c}\text { Reference } \\
\text { Total }\end{array}$ & $\begin{array}{c}\text { Classified } \\
\text { Total }\end{array}$ & $\begin{array}{c}\text { Number } \\
\text { Correct }\end{array}$ & $\begin{array}{c}\text { Producers } \\
\text { Accuracy }\end{array}$ & $\begin{array}{c}\text { Users } \\
\text { Accuracy }\end{array}$ & Kappa \\
\hline Built-up & 14 & 11 & 8 & $57.14 \%$ & $72.73 \%$ & 0.7111 \\
$\begin{array}{l}\text { Thick } \\
\text { vegetation }\end{array}$ & 64 & 122 & 62 & $96.88 \%$ & $50.80 \%$ & 0.3390 \\
$\begin{array}{l}\text { Rocky/Bare } \\
\text { surfaces }\end{array}$ & 15 & 27 & 9 & $60.00 \%$ & $33.33 \%$ & 0.2908 \\
$\begin{array}{l}\text { Water Body } \\
\text { Sparse }\end{array}$ & 2 & 2 & 2 & $100.00 \%$ & $100.00 \%$ & 1.0000 \\
$\begin{array}{l}\text { Vegetation } \\
\text { Totals }\end{array}$ & 155 & 87 & 81 & $52.26 \%$ & $93.10 \%$ & 0.8185 \\
\multicolumn{1}{c}{ Overall Classification Accuracy } & & & & & \\
\hline
\end{tabular}

As shown in table 3 and Figures 5 and 6, the built-up in 2001 increased rapidly from $4.5 \%$ to $7.4 \%$. We can quickly conclude that this is a direct result of the movement of the new capital territory from Lagos to Abuja in 1980. 

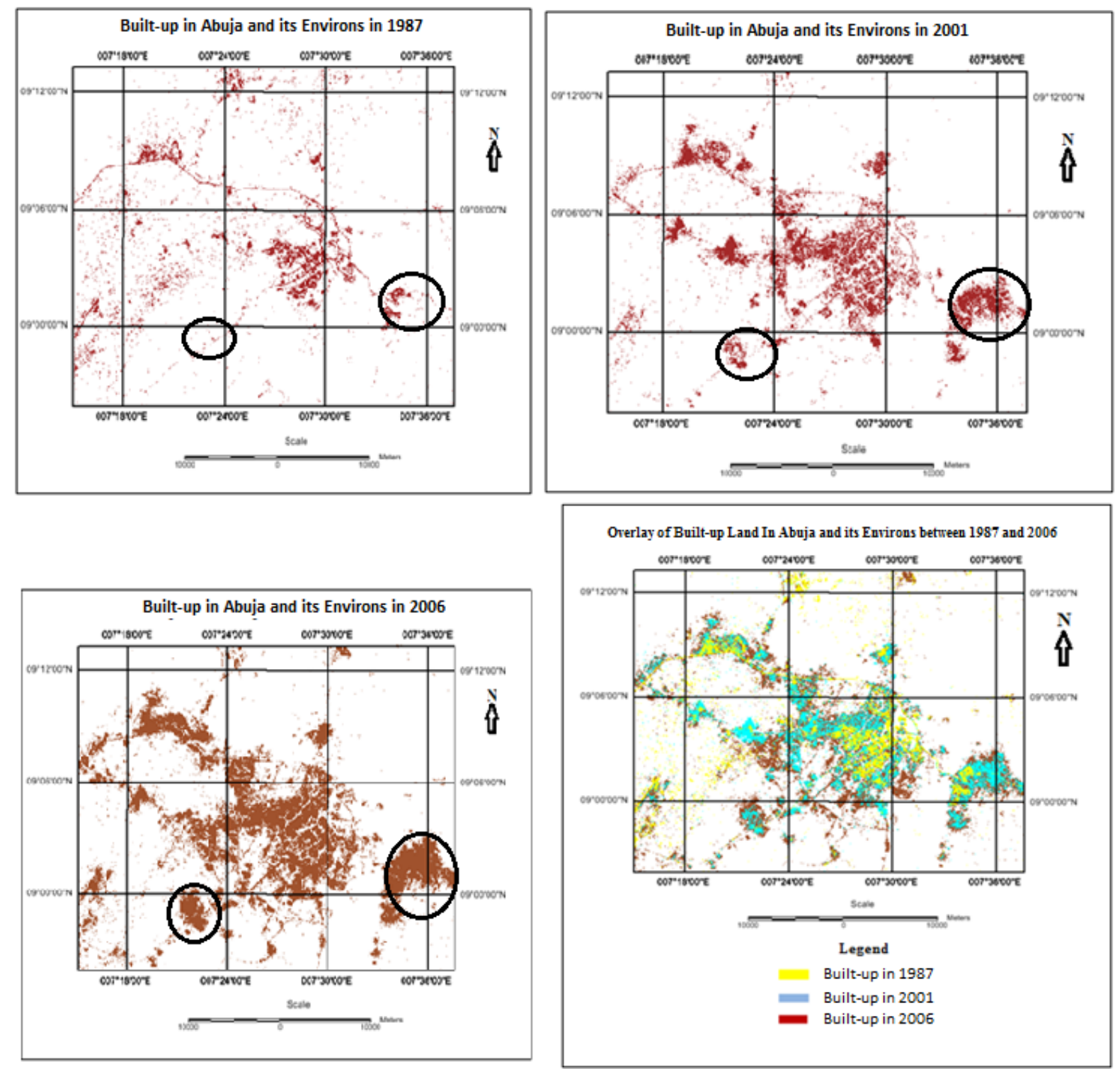

Figure 6. Overlay of built-up between 1987 and 2006

As mentioned earlier, though movement to Abuja was originally meant to be in phases, by 2001, it became accelerated due to emerging opportunities at that time. The vegetation of the area suffered due to massive construction going on at this time. This is well exemplified in the reduction witnessed in thick vegetation from $46.2 \%$ in 1987 to $20.4 \%$ and an increase in bare/rocky surfaces from $15.9 \%$ to $34.2 \%$ in 2001 . However, there was a slight increase in sparse vegetation. One possible explanation to this could be that thick vegetation was cleared but not at the rate construction work was going on; hence the cleared vegetation began to grow sparsely again. As noted by Bello (2009), many of the cleared but abandoned locations became attractive to migrants, who do not have access to approved lands. Hence, the emergence of squatter settlements. 
Table 7. Accuracy and Kappa total for 2001

\begin{tabular}{lllllll}
\hline Class Name & $\begin{array}{l}\text { Reference } \\
\text { Total }\end{array}$ & $\begin{array}{l}\text { Classified } \\
\text { Total }\end{array}$ & $\begin{array}{l}\text { Number } \\
\text { Correct }\end{array}$ & $\begin{array}{l}\text { Producers } \\
\text { Accuracy }\end{array}$ & $\begin{array}{l}\text { Users } \\
\text { Accuracy }\end{array}$ & Kappa \\
\hline $\begin{array}{l}\text { Built-up } \\
\text { Thick }\end{array}$ & 37 & 22 & 21 & $56.76 \%$ & $95.45 \%$ & 0.9466 \\
$\begin{array}{l}\text { vegetation } \\
\text { Rocky/Bare }\end{array}$ & 59 & 43 & 38 & $64.41 \%$ & $88.37 \%$ & 0.8478 \\
$\begin{array}{l}\text { surfaces } \\
\text { Water Body }\end{array}$ & 20 & 88 & 25 & $83.33 \%$ & $28.41 \%$ & 0.1865 \\
$\begin{array}{l}\text { Sparse } \\
\text { Vegetation }\end{array}$ & 122 & 1 & 1 & & & \\
$\begin{array}{l}\text { Totals } \\
\text { Overall Classification Accuracy }\end{array}$ & 96 & 77 & $63.11 \%$ & $80.21 \%$ & 0.6134 \\
\hline
\end{tabular}

Table 8. Accuracy and Kappa total for 2006

\begin{tabular}{|c|c|c|c|c|c|c|}
\hline Class Name & $\begin{array}{c}\text { Reference } \\
\text { Total }\end{array}$ & $\begin{array}{c}\text { Classified } \\
\text { Total }\end{array}$ & $\begin{array}{l}\text { Number } \\
\text { Correct }\end{array}$ & $\begin{array}{l}\text { Producers } \\
\text { Accuracy }\end{array}$ & $\begin{array}{c}\text { Users } \\
\text { Accuracy }\end{array}$ & Kappa \\
\hline Built-up & 54 & 53 & 45 & $83.33 \%$ & $84.91 \%$ & 0.8075 \\
\hline $\begin{array}{c}\text { Thick } \\
\text { vegetation }\end{array}$ & 57 & 40 & 32 & $56.14 \%$ & $80.00 \%$ & 0.7409 \\
\hline $\begin{array}{c}\text { Rocky/Bare } \\
\text { surfaces }\end{array}$ & 24 & 24 & 9 & $37.50 \%$ & $37.50 \%$ & 0.3086 \\
\hline Water Body & 4 & 3 & 3 & $75.00 \%$ & $100.00 \%$ & 1.0000 \\
\hline Sparse & 111 & 129 & 98 & $88.29 \%$ & $75.97 \%$ & 0.5678 \\
\hline Vegetation & & & & & & \\
\hline Totals & 250 & 250 & 187 & \multirow{2}{*}{\multicolumn{2}{|c|}{ Overall Kappa Statistics }} & 0.6290 \\
\hline \multicolumn{3}{|c|}{ Overall Classification Accuracy } & $74.80 \%$ & & & \\
\hline
\end{tabular}

A careful look at Figure 6 shows the remarkable growth witnessed in built-up at this time from $7.4 \%$ in 2001 to $17.8 \%$ in 2006 . At this time, the city had fully developed as a capital city thereby attracting population from all the remaining States of the federation. Many Ministries, Departments and Agencies had moved to the FCT and people were forced to move with them. Indeed the annual rate of growth in built-up at 0.52 at this time is high by all standards. The significance of this growth rate is in the implications for infrastructural provision and environmental degradation in the area. Given the Nigerian situation, where oftentimes, basic infrastructural facilities are provided by individual landlords, and haphazardly too. This led to the development of slums and squatter settlements within and in the neighboring states of the FCT. Thick vegetation and bare/rock surfaces continued to decrease at this time while the encouragement of green space in the city raises sparse vegetation slightly as shown in Table 3 .

A careful look at Figure 6, which is an overlay of the built-up in 1987, 2001 and 2006 shows the pattern of growth. There was a general increase from the city center towards the outskirt of Abuja. This is indeed the case as government began to open up roads at the outskirt of Abuja and more estates and private houses began to spring up at the outskirt to decentralize the city center which was becoming overpopulated. Indeed many government Agencies and Ministries were relocated from the city center towards the outskirts to decongest the center. However, because provision for adequate housing was not in place and indeed is still a major problem for many low income earners working in the city, many resulted into acquisition of illegal lands from village chiefs while others settled in neighboring areas located in neighboring States, where the city administrators had no jurisdiction. Indeed, shanty settlements began to grow within the FCT itself which became a concern for the city 
administrators. This was the situation with Lagos, the former Federal capital of Nigeria. Notably, many of these villages had been compensated and told to relocate. However, provisions were not made for areas to relocate to. Further, because there were no immediate enforcements, many of the villages did not respect the relocation order. These local communities later became highly attractive for low income earners who could not afford houses at the city center. Some of these villages include; Lugbe area, Pyakasa, Chika, Garki among others. However, because the FCT and its neighboring areas should be prevented from wearing the look of typical slums which is associated with many Nigerian and other African cities, the government of the day started massive demolition exercise that took place in Abuja at this time, which many have criticized because of its massive property lost, rendering people homeless. The administration at this time provided no relief to residents affected by the demolition process; a situation that caused hardship to the affected people.

\section{Conclusions}

This study showed that a medium resolution satellite image such as Landsat could be used as proxy for identifying squatter settlements when adequate field verification is carried out to support findings from the image. While high resolution satellite images such as Quickbird or Ikonos images would have been better, the high cost of these images make them less desirable for use in this type of study. However, medium resolution images would still provide a better option than ground surveys in terms of the time it will save, its synoptic capability, time series and coverage. Further, because most medium resolution images are free, cost associated with this type of study is greatly reduced.

From the analysis obtained, it is obvious that the selected study area demands attention of planners and the government of Nigeria. As a matter of fact, despite the demolition exercise that took place aggressively in 2006/07 and the rather occasional demolition exercises still going on, some areas within the core of Abuja still harbors illegal settlements of sizeable number particularly along the airport road. The process of demolition of illegal buildings though painful and wasteful is necessary, but can be avoided if pro-active actions on the part of the authorities are taken.

This study reveals the consequences of urbanization using the Federal Capital City of Nigeria as a case study. The implications of such urbanization without adequate housing infrastructure leading to the development of new patterns in neighboring areas were examined. The paper shows the need to develop the Federal Capital City of Nigeria smartly. Though urbanization is necessary, and inevitable due to population increase, however, growth must be planned and must include the urban poor in the planning process. This will ensure that the quality of urban environment will not become very poor for human health and living. In view of these, the following recommendations are made to encourage the smart growth of the city;

\subsection{Recommendations}

i. In order to check the rapid growth of informal settlements without causing huge economic hardship on the affected inhabitants in the FCT, the Federal Capital Development Authority (FCDA) should embark on elaborate enlightenment and awareness campaign on the consequences of informal settlements in the study area.

ii. Access to land for residential buildings by the inhabitants should be made easier than it currently obtains.

iii. The FCDA should put in place low-cost housing programs across all the Area Council to minimize the emerging rate of informal settlements in the FCT. This could be through the encouragement of public-private partnerships.

iv. Periodic satellite image monitoring and mapping of the entire FCT is imperative as a means of detecting and controlling informal settlements across the territory.

v. Efforts should be made by concerned authorities to relocate residents of these informal settlements to a planned location

vi. Where it is practically impossible to relocate residents of in the squatter settlements to a planned area, an upgrade of the existing squatter settlements should be considered.

\section{References}

Abuja. (2014). Abuja: National Capital, Nigeria. Encyclopedia Britannica. Retrieved from http://www.britannica.com/EBchecked/topic/2397/Abuja 
Ade, M. A., \& Afolabi, Y. D. (2013). Monitoring Urban Sprawl in the Federal Capital Territory of Nigeria Using Remote Sensing and GIS Techniques. Ethiopian Journal of Environmental Studies and Management, 6(1), 82-95. http://dx.doi.org/10.4314/ejesm.v6i1.10

Ayileka, O., \& Kalgo, M. S. U. (2001). The Review of Abuja Master Plan (Ed.). Proceedings of an International Workshop for the Review of the Abuja Master Plan. Abuja, Nigeria: Ministry of the Federal Capital Territory

Bello, O. M. (2009). Squatter Settlement, Accessibility of Land and the Urban Poor. FIG Working Week 200. Surveyors Key Role in Accelerated Development. Eilat, Israel. Retrieved from http://www.fig.net/pub/accra/papers/ts18/ts18_01_jibril.pdf

Brunhes, J. (1925). La GegrahieHumaine. Paris.

Burchell, R. W., Shad, N. A., Listokin, D., Phillips, H., Downs, A., Seskin, S., Davis, J. S. .. \& Gall, M. (1998). The Costs of Sprawl--Revisited. Transit Cooperative Research Program (TCRP) (39). Transportation Research Board, Washington. Retrieved from http://www.worldtransitresearch.info/research/2965/

Campbell, B. J. (1987). Introduction to Remote Sensing. The Guilford Press, New York, p 340. http://dx.doi.org/10.1080/10106048709354126

Dumashie, A. D. (2006). People and Places: The Importance of the Supply of Land in Delivering Affordable Housing in Informal Settlements. Promoting Land Administration and Good Governance. 5th FIG Regional Conference Accra, Ghana. Retrieved from http://www.fig.net/pub/accra/papers/ts03/ts03_02_dumashie.pdf

Duncan, J. E. et al. (1989). The search for efficient urban growth patterns. Tallahassee, FL: Florida Department of Community Affairs.

Federal Capital Territory Administration. (2011). Facts. Retrieved from http://www.fct.gov.ng/index7732.html?option=com_content\&view=article\&id=45\&Itemid=87

Federal Government of Nigeria. (1990). Laws of the Federation of Nigeria. Federal Capital Territory Act. $\begin{array}{llll}\text { Chapter. } & \text { Abuja-Nigeria. } & \text { Retrieved }\end{array}$ http://www.nigeria-law.org/Federal\%20Capital\%20Territory\%20Act.htm

Frank, J. E. (1989). The costs of alternative development patterns: a review of the literature. Washington, DC: Urban Land Institute.

Freeman, L. (2001). The effects of sprawl on neighborhood social ties. Journal of the American Planning Association, 67, 69-77. http://dx.doi.org/10.1080/01944360108976356

Herold, M., Goldstein, M. C., \& Clarke, K. C. (2003). The spatiotemporal form of urban growth: Measurement, analysis and modeling. Remote Sensing of Environment, 86, 286-302.

Hofmann, P., Strobl, J., Blaschke, T., \& Kux, H. (2008). Detecting informal settlements from QuickBird data in Rio de Janeiro using an object based approach. Object-Based Image Analysis: Spatial Concepts for Knowledge-Driven Remote Sensing Applications, http://dx.doi.org/10.1007/978-3-540-77058-9_29

Jensen, J. R. (2005). Introductory to digital image processing: a remote sensing perspective. Upper Saddle River, NJ, USA: Prentice Hall.

Ji, W. (2008). Landscape effects of urban sprawl: Spatial and temporal analyses using remote sensing images and landscape metrics. The International Archives of the Photogrammetry, Remote Sensing and Spatial Information Sciences. Vol. XXXVII. Part B7. Beijing. Retrieved from http://www.isprs.org/proceedings/XXXVII/congress/7_pdf/10_ThS-18/28.pdf

Jibril, U. I. (2006). Resettlement Issues, Squatter Settlements and Problems of Land Administration in Abuja, Nigeria's Capital: Promoting Land Administration and Good Governance. 5th FIG Regional Conference Accra, Ghana. Retrieved from http://www.fig.net/pub/accra/papers/ts18/ts18_01_jibril.pdf

Lillesand, M. T., KIefer, W. R., \& Chipman, N. J. (2008). Remote Sensing and Image Interpretation (6th ed.). John Wiley and Sons, Inc, New York.

Mabogunje, A. L. et al. (1977a). Report of the Ecological Survey of the Federal Capital Territory (Vol. I). The Environment. University of Ibadan Consultancy Services, Nigeria.

Mabogunje, A. L. et al. (1977b). Population, Settlement and Resettlement in the Federal Capital Territory (Vol. II). University of Ibadan Consultancy Services, Nigeria. 
Mesev, V. (Ed.). (2003). Remote sensed cities. Taylor \& Francis, London.

Moeller, M. (2005). Remote sensing for the monitoring of urban growth patterns. In M. Moeller, \& E. Wentz (Eds.), The International Archives of the Photogrammetry, Remote Sensing and Spatial Information Sciences (Vol. XXXVI - 8/W27).

National Population Commission. (2006). State population. Retrieved fromhttp://www.population.gov.ng/index.php/state-population accessed on 05/29/2013

Ojigi, M. L. (2006). Analysis of Spatial Variations of Abuja Land Use and Land Cover from Image Classification Algorithms. ISPRS Commission VII Mid-Term Symposium. Theme: Remote Sensing: From Pixel to Processes. Enschede, The Netherlands.

Ojigi, M. L. (2012). An Evaluation of the Efficiency of the Land Use Act 1978 of the Federal Republic of Nigeria and its Implications in Minna and Environs (TS01E - Pro Poor Land Management, 5577). International Federation of Surveyors (FIG) Working Week: Knowing to manage the territory, protect the environment, and evaluate the cultural heritage. Rome Italy.

Okoro, M. J. (2014). Assessing the environmental health hazards and housing development in the slums of Abuja, FCT. Munich, GRIN Publishing GmbH. Retrieved from http://www.grin.com/en/e-book/280701/assessing-the-environmental-health-hazards-and-housing-developm ent-in-the

Olorunfemi J. F. (1983). Monitoring Urban Land - Use in Developing Countries - An aerial photographic approach. Environmental Int., 9, 27-32. http://dx.doi.org/10.1016/0160-4120(83)90111-3

Senseman, M. G., Calvin, B. F., \& Tweddale, S. A. (1995). Accuracy Assessment of the Discrete Classification of Remotely-Sensed Digital Data for Land cover Mapping. SACERL Technical Report EN-95/04, 1-35.

Tanable, R. (2012). Abuja. New World Encyclopedia. Retrieved from http://www.newworldencyclopedia.org/p/index.php?title=Abuja\&oldid=963235

Ukoje, J. E., \& Kanu, K. U. (2014). Implementation of the Challenges of the Mass Housing Scheme in Abuja, Nigeria. American International Journal of Contemporary Research, 4(4), 209-218. Retrieved from http://www.aijcrnet.com/journals/Vol_4_No_4_April_2014/27.pdf

UN-HABITAT. (2006). http://www.unchs.org/programmes/guo/statistics.asp

UNSTAT. (2005). Environmental Glossary. Retrieved from http://unstats.un.org/unsd/environmentgl/gesform.asp?getitem=665

Wang, H., He, S., Liu, X., Dai, L., Pan, P., Hong, S., \& Zhang, W. (2013). Simulating urban expansion using a cloud-based cellular automata model: A case study of Jiangxia, Wuhan, China. Landscape and Urban Planning, 110, 99-112. http://dx.doi.org/10.1016/j.landurbplan.2012.10.016

Zubair, A. O. (2008). Monitoring the Growth of Settlements in Ilorin, Nigeria (A GIS and Remote Sensing Approach). The International Archives of the Photogrammetry, Remote Sensing and Spatial Information Sciences (Vol. XXXVII; Part B6b). Retrieved from Beijing. http://www.isprs.org/proceedings/XXXVII/congress/6b_pdf/37.pdf

\section{Copyrights}

Copyright for this article is retained by the author(s), with first publication rights granted to the journal.

This is an open-access article distributed under the terms and conditions of the Creative Commons Attribution license (http://creativecommons.org/licenses/by/3.0/). 